\title{
Chapter 7 \\ Crackdown or Symbolism? An Analysis of Post-2015 Policy Responses Towards Rejected Asylum Seekers in Austria
}

\author{
Ilker Ataç and Theresa Schütze
}

\subsection{Introduction ${ }^{1,2}$}

In 2015, Austria served as both a transit and a host country to asylum seekers from war-ridden regions. The numbers of applications for asylum increased dramatically, transit centres were set up, and people moved through the country on their way to Germany and Sweden. Already in the fall of 2015, only a few weeks after the borders were temporarily opened without controlling the persons who crossed, Austrian politicians began to prioritise a tough stance towards migration and asylum. The government also changed its approach towards non-removed rejected asylum seekers (NRAS). In early 2016, the national government proclaimed the ambitious plan to deport at least 50,000 persons by the end of 2019. In so doing, Austrian government representatives constituted no exception to state leaders across Europe, who have since 2015 prioritised the enforcement of removals (EMN 2017; Lutz 2018). Subsequently, the federal government proposed and adopted several measures with the aim of fostering return enforcement. However, some of these policies are symbolic, aimed at signalling to the public certain values and the government's commitment to this goal. In sum, the federal government pursued a shift of policies towards a very narrow and one-sided response to the presence of NRAS through a mix of substantive and symbolic policy measures.

\footnotetext{
${ }^{1}$ This paper is based on the research project "Inside the Deportation Gap. Social Membership for Non-Deported Persons" supported by the Austrian Science Fund (FWF) under grant agreement number P 27128-G11.

${ }^{2}$ We would like to express our gratitude to Sieglinde Rosenberger for her extremely helpful feedback and comments on this paper.
}

\section{Ataç $(\bowtie) \cdot$ T. Schütze}

Department of Political Science, University of Vienna, Vienna, Austria

e-mail: ilker.atac@univie.ac.at; theresa.schuetze@univie.ac.at 
In this chapter, we analyse the federal government policies regarding NRAS in Austria in response to the events that occurred after the 'refugee crisis' in 2015. We attempt to answer the following research questions: (1) To what extent are policy responses towards NRAS substantive measures to control and deter them in order to foster the deportation regime, and to what extent do they represent symbolic measures directed towards voters? (2) How can we explain the emergence of symbolic, substantive or both types of policy responses through the particularities of NRAS?

We employ the analytical perspective of substantive and symbolic policy responses towards irregular migration that differentiates between two fundamental functions that policies can serve: signalling vs. intervention (Slaven and Boswell 2018). Together they address a wide range of aims, from creating a hostile environment and disincentives to stay or come (Triandafyllidou and Ambrosini 2011; Lahav and Guiraudon 2006) to policies that criminalize (Hammerstad 2014), incarcerate (Schmoll 2016), and mark migrants as a threatening figure (Bosworth 2008). Following Bagley and Ward, we define policy responses as both actions (by governments) to solve problems and actions to "persuade social actors to subscribe to particular beliefs that delineate action" (2013: 1).

We focus on NRAS and follow Heegaard Bausager et al. (2013) in defining NRAS as those who have been issued a negative decision to their asylum claim and are therefore under the legal obligation to leave the country but have been neither forcefully deported nor departed on their own. NRAS constitute a growing segment of European society. According to the European Commission (2015), in 2015 about $40 \%$ of return decisions were processed in the European Union; in Austria, around $50 \%$ (Table 7.1). Even if nation-states are successful in increasing return rates in the years to follow, it seems unlikely that the number of non-removable returnees will significantly decrease (cf. Lutz 2018: 50). The European Commission estimates that more than one million people in Europe will soon become rejected asylum seekers (EU Commission 2017).

This chapter contributes to the existing literature by investigating policy responses in the field of asylum and return, and by providing detailed insights into the interplay of the symbolic and substantive dimension of policies against irregular migration. In the next section, we provide an overview of the theoretical literature that inspired the evaluation and analysis of our empirical collection of policy responses to NRAS. In Sect. 7.3, we explain why we understand NRAS as a subcategory of irregular migrants and present our methodology. Section 7.4 provides a synopsis of relevant information of the Austrian context. In Sect. 7.5, we present the empirical findings, followed by a discussion of why a mix of substantive and symbolic policies emerges in Austria. 
Table 7.1 (Non-cumulative) deportation gap of third-country nationals and number of rejected asylum applications in Austria between 2008 and 2017

\begin{tabular}{l|l|l|l|l|l|l|l|l|l|l}
\hline Austria & 2008 & 2009 & 2010 & 2011 & 2012 & 2013 & 2014 & 2015 & 2016 & 2017 \\
\hline $\begin{array}{l}\text { Final rejected } \\
\text { asylum } \\
\text { applications }\end{array}$ & 16,255 & 21,660 & 19,425 & 16,695 & 17,850 & 17,125 & 3440 & 8440 & 14,145 & 29,315 \\
\hline $\begin{array}{l}\text { 3rd country } \\
\text { nationals } \\
\text { ordered to } \\
\text { leave }\end{array}$ & 8870 & 10,625 & 11,050 & 8520 & 8160 & 10,085 & N/A & 9910 & 11,850 & 8850 \\
\hline $\begin{array}{l}\text { 3rd country } \\
\text { nationals } \\
\text { returned, } \\
\text { following } \\
\text { order to leave }\end{array}$ & 5855 & 6410 & 6335 & 5225 & 4695 & 6790 & 2480 & 5275 & 6095 & 6115 \\
$\begin{array}{l}\text { Additional } \\
\text { "deportation } \\
\text { gap" per year } \\
\text { third country } \\
\text { nationals) }\end{array}$ & $\mathbf{3 0 1 5}$ & $\mathbf{4 2 1 5}$ & $\mathbf{4 7 1 5}$ & $\mathbf{3 2 9 5}$ & $\mathbf{3 4 6 5}$ & $\mathbf{3 2 9 5}$ & N/A & $\mathbf{4 6 3 5}$ & $\mathbf{5 7 5 5}$ & $\mathbf{2 7 3 5}$ \\
\hline
\end{tabular}

Source: Own compilation based on the following tables from Eurostat: migr_eiord (http://ec. europa.eu/eurostat/web/products-datasets/-/migr_eiord), migr_eirtn (http://ec.europa.eu/eurostat/ web/products-datasets/product?code=migr_eirtn), first instance decisions (http://ec.europa.eu/ eurostat/tgm/table.do?tab=table \&plugin=1\&language $=$ en $\&$ pcode $=$ tps00192) and final decisions (http://ec.europa.eu/eurostat/tgm/refreshTableAction.do?tab=table \&plugin=1\&pcode=tps00193 \&language $=$ en), as well as research on metadata information of Eurostat

${ }^{a}$ The phrase additional deportation gap means that this figure needs to be added to the already existing cumulative number of non-deported persons in Austria from previous years. However, it is much harder to assess the original size of the group to which each year's deportation gap would be added in order to then be able to estimate the overall size of the existing deportation gap at any given moment

\subsection{Theorising Policies Towards Irregular Migrants and NRAS}

Academic literature from the last two decades provides us with insights on policies developed and implemented to control irregular migrants in European countries. As a subcategory of irregular migrants, this literature serves as an instructive contrasting foil to discuss the commonalities and particularities of policies towards NRAS.

To systematise these policies, the literature differentiates between external and internal control policies. External control policies are defined as policy measures developed to control irregular migration at state borders as well as through cooperation with other states and private companies (Triandafyllidou and Ambrosini 2011; Lahav and Guiraudon 2006). In contrast, internal control policies are actions that concern immigrants staying inside a nation's borders. In this paper, we focus on internal control policies to understand how those boundaries that physically and symbolically separate politically undesired yet present rejected asylum seekers from other parts of society on the same territory are created and enforced. 
To understand policies concerning irregular migrants, the literature provides us with another important differentiation - that of substantive versus symbolic policies to deal with irregular migration. Following Slaven and Boswell, we understand substantive policies as "measures to steer the object of intervention", whereas the common basic property of symbolic policies is that they are "high profile measures" and "cosmetic policy adjustments" primarily intended to "signal values and intent" (2018: 1), usually directed at the voting population. While the two do not necessarily contradict each other in practice, they follow different fundamental aims, namely those of steering (substantive policies) vs. signalling (symbolic policies).

Substantive policies against irregular migration discussed in recent academic literature are mainly centred on detention as the most prevalent form of confinement. Detention works as an instrument of immigration control as well as "a wider instrument of control of "undesirable foreigners"' (Majcher and de Senarclens 2014: 4). Detention policies include punitive elements and, far from fulfilling only an administrative function of physical control, are intended to deter irregular residence and enforce return of irregular migrants (Leerkes and Broeders 2013).

Deterrence measures describe policies intended to make migrants' everyday living situation difficult with the aim of discouraging individuals from migrating irregularly or staying in a country without a legal residence permit (Schmoll 2016). Their substantive aim is to steer the behaviour of the target group (s. Slaven and Boswell 2018: 3). As Hamlin (2012) shows, the use of deterrent policies is not limited to irregular migrants but extends to asylum seekers by reducing incentives for making asylum applications through strict border control, time limits, narrowing the grounds for asylum, removing workers' rights for asylum seekers, and putting increasing numbers of asylum seekers in detention (cp. Schuster 2011; Scheel and Squire 2014). Besides harsh treatment through punishment and detention, another deterrent measure is cutting off welfare benefits such as access to public services, accommodation, and health services for irregular migrants. Exclusion from welfare benefits became a means of immigration control, a trend heightened in the 2000s in relation to asylum seekers and irregular migrants (Ataç and Rosenberger 2018).

In the past decades, scholars have argued that these mostly restrictive, substantive measures are unlikely to achieve the promised outcome of full state control of irregular migration for various reasons. On the one hand, liberal constraint theorists argue that international human rights obligations and the re-enforcement of individual rights and their extension to minority immigrant groups in the post-war era restrain restrictive and punitive policies towards irregular migrants (Hollifield et al. 2014; Joppke 1998). Another dominant line of argument is that such policies do not address the global structural forces underlying migration (Massey et al. 2005; Sassen 1988). These limits to substantive, restrictive national policies against irregular migration render the use of "symbolic policy instruments to create an appearance of control" more attractive (Massey et al. 2005: 288) and indicate why they are particularly present in this field (Castles 2004: 867; Triandafyllidou 2010: 17; Slaven and Boswell 2018).

Symbolic migration policies are closely connected to processes of securitisation and criminalisation. On the one hand, migrants are constructed as threats to 
communal cohesion and national identity through policy efforts that bring them under the realm of security and military policy (Hansen 2014). Ceyhan and Tsoukala emphasize the importance of the symbolic dimension of policies for the construction of migrants as a threat (2002: 23), the effectiveness and success of which in turn rely upon mass media to reach discursive significance (s. Rheindorf and Wodak 2018:21). Scholars also debate the convergence between migration and criminal law, depicted as crimmigration (Stumpf 2006). Hence, securitisation/crimmigration presents the symbolic dimension detention policies, for example, and other policies that constitute a comparable handling of (irregular) migrants and offenders. On the other hand, securitisation and 'crimmigration' are discursive phenomena preceding concrete policies, which help legitimise harsh treatment and punitive measures against irregular migrants by constructing them as a security issue in the first place (Bigo 2005). However, the short-term benefits of securitisation and criminalisation for policy makers - to draw public attention to policy measures and the appearance of a strong commitment-bear the risk of increasing pressure on authorities in the long term, due to risen public anxiety (cf. Slaven and Boswell 2018: 15f).

Slaven and Boswell (2018) have identified three drivers of symbolic policies towards irregular migration: (a) manipulation, the use of (often security-related) narratives addressing morality, affection, and emotions to generate public support; (b) compensation, the use of bold and simple measures to divert attention from the gap between public preference for restrictive measures and a state's ability or willingness to effectively implement such measures (s. Joppke 1998; Hollifield et al. 2014); and (c) adaptation, which refers to the discrepancy of knowledge on irregular migration between the implementing apparatus 'inside' and the voting public 'outside', and the adjustment of public policy to popular narratives.

Through the analytical differentiation between measures designed to change the reality of a certain issue on the ground and those targeting mostly the public perception of how an issue is handled policy-wise, we may better understand how the mix of both measures are used in a strategic way to achieve certain objectives. Moreover, just like symbolic policies may have real effects on the issue at stake as well as the "intended audiences" (Slaven and Boswell 2018: 3), substantive policies also (re) produce societal norms on how a subject is handled and influence the way it is perceived. In other words: Signals also steer, and steering sends signals. Connecting to the interrelatedness of substantive and symbolic measures, Bosworth explains how punishment and detention measures towards irregular migrants have both a symbolic as well as material dimension: "Prisons or immigration removal centres are singularly useful in the management of non-citizens because they enable society not only physically to exclude this population, but also, symbolically to mark these figures out as threatening and dangerous" (2008: 207-8).

Based on these conceptual debates on policies towards irregular migrants, we analyse policy responses directed at NRAS. Often, the literature does not explicitly consider policies on NRAS (notable exceptions are Cantor et al. 2017; Heegaard Bausager et al. 2013; Lutz 2018; Rosenberger and Koppes 2018; Schoukens and Buttiens 2017), and until now no account of policies for NRAS has been empirically explored and systematically discussed. This chapter aims to begin a new conversation about this literature and conceptual work. 


\subsection{Case and Methods}

Irrespective of whether a rejected asylum seeker is not removed just yet or whether long-term impediments to the removal exist, he or she lives in a legal status of irregularity as long as the obligation to leave the country remains upright and no temporary residence status is given. We therefore define NRAS as a sub-category of irregular migrants. In the group definition we include persons holding a toleration card, since this formal postponement of removal has no legalising effect on the person's residence status (Triandafyllidou 2010: 6). While the group of non-removed irregular migrants reflects a variety of different trajectories, in this article we focus specifically on NRAS for two reasons. First, rejected asylum seekers have been particularly present in the public debate after asylum applications in Austria increased significantly in 2015 and 2016. Second, they constitute by far the biggest sub-group of non-removed persons who benefit from basic welfare support. We assume that the latter stems at least in part from the circumstances that NRAS (compared to other non-removed persons) have been in contact with authorities and a part of public services throughout the course of their asylum-seeking process.

In order to assess the policy responses directed at NRAS in Austria since 2015, we undertook a qualitative content analysis of parliamentary documents and media coverage. The former consisted of a body of government programs, parliamentary debates, stakeholder commentaries to legal amendments, and press releases that specifically referred to policy proposals regarding NRAS. To investigate the media coverage, we created a database of articles about policies on NRAS in one renowned nationwide newspaper (der Standard) through the Austria Press Agency (APA). The time period of analysis spans from the refugee movements in September 2015 until November 2017, shortly before the former government coalition left office and when the most recent amendments on aliens related laws came into force. ${ }^{3}$ We carried out four rounds of data collection using the search terms 'asylum seeker', 'reject', 'deport', 'illegal', 'negative', 'basic welfare', and 'refugee' in varying combinations. Based on a close reading of the government documents and media articles and through the use of the qualitative data analysis software Atlas.ti we created a detailed timeline of policy proposals by the government. This chronology of policy responses was supplemented by information on the status and content of each policy, whereby the media analysis was particularly helpful in identifying unadopted policy proposals and their significance to communicate political will.

We distinguish policy responses according to their status in the policy cycle and differentiate between tabled and adopted policy responses. Tabled policy responses refer to government policy proposals that are debated but have not (yet) come to a resolution (a legal or administrative adoption). By contrast, adopted policies or

\footnotetext{
${ }^{3}$ The assessment period comprises activities of the preceding coalition government between Social Democrats and the conservative Austrian People's Party. The activities of the right wing-conservative government which took office in December 2017 are excluded from the analysis since its time in office is hitherto too short to comprehensively retrace policy developments.
} 
actions are geared towards measures already in use, either at the implementation or legislation level. In so doing, we attempt to gain a systematic understanding about whether a proposal remains political talk or whether a policy measure is passed. Following Czaika and de Haas (2013), we look at the divergence between tabled and adopted policies to operationalize the search for a potential "discourse gap", meaning the difference between public discourse and actual policies on paper. Such differentiation informs us about the kind of symbolic policies that intervene in the discourse and may alter the political climate and public perception of the government's approach without actually becoming manifest rules, i.e., translated into official policy. The second kind of symbolic policy responses that we aim to identify are adopted as official policy but remain "action for show" because they are not sustainably pursued (Rein 2008: 394; for a similar definition of symbolic policy s.a. Delaney 2002: 7; Krause 2011: 46; van der Leun 2006), implying that "the superficial and short-term reassurance of the electorate is the main aim of political actions" (Triandafyllidou 2010: 17). For this kind of symbolic policy, e.g. the enforcement of deportations in military planes, the prevalence in media articles served as an indicator for "the show".

In addition, the analysis of the period before 2015 in this chapter is based on a comparative research project in which we analysed access to welfare services for NRAS in Austria, the Netherlands, and Sweden. The data collected in the course of the project consist both of legal and policy documents and media reports as well as 73 semi-structured qualitative expert interviews we conducted between June 2016 and July 2017-25 of them in Austria — with academics, lawyers, and policymakers at the national and local government levels, as well as with representatives of NGOs with expertise in the situation of non-removed persons.

\subsection{Inside the Deportation Gap in Austria}

Due to instability, war, and crises in the Middle East and other parts of the world, record numbers of asylum seekers have arrived in the territory of the European Union (EU) since 2015. This resulted in 1,322,825 asylum applications filed in the EU in 2015 and 1,258,865 in 2016 (Schoukens and Buttiens 2017). Among European countries, Austria received the third-largest number of asylum applications per capita after Sweden and Hungary in the 12 months from July 2015 to June 2016 (Eurostat 2018). In total, in Austria 88,340 asylum applications were made in 2015 and 42,285 in 2016 (BMI 2016). While the number of asylum applications that were accepted increased in relative terms after 2015, the absolute number of rejected asylum applications rose simultaneously with the overall number of applications.

This results in an overall growing deportation gap (Gibney 2008), which describes the numerical difference between return orders and de facto returns. The overall, cumulative, deportation gap must logically be growing as long as more persons are ordered to leave each year than actually return or are deported. This overall gap can only be very roughly estimated, since the whereabouts of absconded 
asylum seekers are usually unknown due to the transnational mobility of irregular migrants to avoid law enforcement targeted at migrants' exclusion (Wyss 2019). We derive an approximation from statistics on orders to leave in a given year and the number of persons returned in the same year. This calculation results in an average deportation gap in Austria of 3903 persons per year between 2008 and 2017 (see Table 7.1). Since the number of rejected asylum seekers in 2017 is quite large, as illustrated in the table above, and returns have not really increased, the deportation gap will very likely continue to grow in subsequent years.

To get a better sense of the diversity of the group, NRAS can be differentiated according to whether their individual situation is formally recognized or not, and whether this implies access to associated rights. Based on an empirical inquiry in the EU and Schengen associated countries, Heegaard Bausager et al. (2013) identified three types of such (non-)recognition of non-removed third-country nationals, namely: a) an official postponement of return granting additional rights, b) an official postponement without additional rights, and c) no formal recognition or formal postponement of return (p. 2f).

Deriving but also departing from this typology, the situation of NRAS in Austria is a bit peculiar. Similar to the first type above, an official postponement of return through a "toleration card" (Duldungskarte) can be granted to NRAS in Austria. However, with around 300 issuances per year (Parlamentarische Anfrage 2016), the numbers of issued toleration cards are very low and feature not only NRAS, but also persons whose subsidiary protection status has been withdrawn. A second, considerably bigger group only has access to services comprised by the basic welfare support system ${ }^{4}$ although their situation is not formally recognized. The number of NRAS in the basic welfare support system has remained relatively stable, growing only slightly from around 3000 persons in 2012 to around 3400 persons in 2017. This group of NRAS fits neither type described above but is highly relevant in Austria. A third group of unknown size is neither formally tolerated nor a factual beneficiary of basic welfare support, consistent with the third type above (see also EMN 2016a). This last group includes NRAS excluded from basic welfare support because they were deemed uncooperative or who exited the system of their own accord. Based on the estimated deportation gap and the number of rejected asylum seekers (see Table 7.1), we conclude that there is a notable group of persons who do not receive welfare services from the state but are nevertheless part of the deportation gap-existing in a state of legal limbo and uncertainty. Numerical data on rejected asylum seekers who find themselves outside this welfare system do not exist.

\footnotetext{
${ }^{4}$ Basic Welfare Support includes health care, the provision of adequate food and basic clothing as well as a monthly allowance for beneficiaries in organised reception facilities (EMN 2016b).
} 


\subsection{Policies Against NRAS}

In this section we will explore national policy responses towards NRAS in Austria. In the first part, we present the policies prior to 2015; in the second part, we look at policies between 2015 and 2017. In the third part, we analyse the policy responses after 2015 by providing detailed insight into how a mix of substantive and symbolic policy measures emerges.

\subsubsection{Policies Before 2015}

In Austria, major policies regarding NRAS date back to 2004. In this year, the Basic Welfare Support Agreement (Grundversorgungsvereinbarung, GVV) was adopted between the federal government and the provinces, as a result of the implementation of the EU Reception Directive (2003/9/CE). This agreement regulates the care of "vulnerable foreigners", including asylum seekers and those entitled to asylum as well as persons who cannot be removed for "legal and factual reasons", including NRAS. According to the agreement, the provinces are primarily responsible for implementing the GVV, while the federal government carries $60 \%$ of the financial costs. In addition, there exist forms of coordinated interaction between the federal state and provinces, such as the coordinating council (Landes-Flüchtlingsreferente nkonferenz), which aims to develop a joint approach for coordinating and harmonising welfare services and their quality. This closely approximates the model of multilevel governance described by Scholten (2013) in which weak central policy coordination structures exist and provinces have strong implementation power.

However, this system is not only a system of coordination and consensus. Conflicts emerged between the province of Vienna and the federal government, as well as amongst the provinces, around the question of strict or generous policy implementation (Ataç 2019). While the federal agency of migration (BFA) requires provinces to dismiss NRAS from the welfare system in case of assumed violation of the cooperation duty, provinces (such as Vienna, Tyrol, and Vorarlberg) have in the past ignored such requests (Rechnungshof 2013). As a result, the federal agency refused to pay its contribution. Also, conflicts between the provinces emerged when some provinces denied NRAS access to welfare services, thereby transgressing the legal agreement (GVV). Consequently, the burden fell on provinces such as Vienna or Tyrol, which offered NRAS these services.

A further important regulation for NRAS took place in 2005 when the Aliens Police Act was amended and preparations made for the status of toleration and the toleration card for non-removed persons to come into force in 2006 ( $\$ 46 \mathrm{a}$ FPG 2005). The toleration card does not provide a residence permit and can be prematurely withdrawn by the federal agency of migration at any time (Hinterberger and Klammer 2015). As a prerequisite for the toleration status, the person concerned must cooperate with return. This means providing correct identity information and 
actively seeking a traveling certificate from the relevant embassy that would enable return. The Aliens Law Amendment Act 2009 created for the first time an opportunity to regularise the residence of persons who cannot be deported for factual reasons. After 1 year of toleration, asylum seekers can apply for "special protection" ( 57 AsylG 2005), which goes hand in hand with legal residence status.

With the Aliens Police Act 2005, detention of NRAS has turned into a popular policy instrument with the aim of fostering their return. The Commissioner for Human Rights of the Council of Europe (2007) has criticized the growing popularity of the practice of detaining asylum seekers and NRAS since 2006. This tendency of placing NRAS in pre-deportation detention remained high until 2010 (Commissioner for Human Rights of the Council of Europe 2012). Thereafter, annual detention numbers started to decrease, from approximately 6200 in 2010 to nearly 1900 in 2014 (Rechnungshof 2016). Reasons for the decrease include changing courts practices, increased focus on voluntary departure, as well as growing reliance on short-term detention (Verwaltungsverwahrungshaft), which is based on arrest orders to secure removal, especially in cases where deportation of NRAS is possible within 72 hours (Global Detention Project 2017).

In sum, before 2015 de facto toleration, that is access to basic welfare services without granting a legal status, was characteristic for the Austrian governance of NRAS. Also, in the period between 2010 and 2015, the detention practices were weakened.

\subsubsection{Policy Responses Post-2015: Fixation on Return}

The policy responses after 2015 demonstrate a radical shift from a policy with temporarily uncontrolled borders for tens of thousands of asylum seekers at the beginning, towards a restrictive standing and the total superimposition of policies with the sole, direct or indirect, focus on return. In this section, we systematically review the policy responses brought forward by the Austrian government towards NRAS post-2015. Within the total of 38 policy measures we found in the field of general asylum and border policies, we discerned 18 distinct policies concerning NRAS (Table 7.2).

Our analysis of these policies leads to three major findings. First, policy responses regarding NRAS have increased significantly since 2015. After the introduction of both main regulations regarding NRAS in 2004 and 2005 described above, the rejected asylum seekers inside the deportation gap were not on the political agenda, and only minor national and regional policy responses emerged prior to 2015 . Moreover, the government programme at this time mostly prioritised voluntary return (Regierungsprogramm 2013: 81).

Second, there is a striking concentration of measures to address NRAS that can be assigned to return policy. Sixteen of 18 identified policy responses are in the field of return. Five legally-adopted policies in the field constitute the core of policies towards NRAS: a much-debated reform package of the Aliens Law Amendment Act 
Table 7.2 Substantive and symbolic polices

\begin{tabular}{|c|c|c|c|}
\hline \multicolumn{3}{|c|}{ internal } & external \\
\hline Substantive policies & \multicolumn{2}{|c|}{ Symbolic policies } & \\
\hline All adopted/implemented & Tabled & Adopted & \\
\hline $\begin{array}{l}\text { Extension of detention pending } \\
\text { deportation (FrÄG 2017) }\end{array}$ & $\begin{array}{l}\text { Criminal procedure } \\
\text { in case of non- } \\
\text { departure }\end{array}$ & & $\begin{array}{l}\text { Extending the list } \\
\text { of 'safe countries } \\
\text { of origin' }\end{array}$ \\
\hline Coercive detention (FrÄG 2017) & $\begin{array}{l}\text { Wider executive } \\
\text { powers for staff in } \\
\text { return centres }\end{array}$ & & $\begin{array}{l}\text { Defining 'safe third } \\
\text { countries' }\end{array}$ \\
\hline $\begin{array}{l}\text { Territorial restriction (FrÄG } \\
\text { 2017) }\end{array}$ & $\begin{array}{l}\text { No } \\
\text { preannouncement of } \\
\text { deportations }\end{array}$ & & $\begin{array}{l}\text { Readmission } \\
\text { agreements with } \\
\text { countries of origin }\end{array}$ \\
\hline $\begin{array}{l}\text { Administrative penalty for non- } \\
\text { departure (FrÄG 2017) }\end{array}$ & Deportations in & military planes & $\begin{array}{l}\text { Tighter } \\
\text { cooperation with } \\
\text { FRONTEX }\end{array}$ \\
\hline \multicolumn{4}{|l|}{ Return centres (FrÄG 2017) } \\
\hline \multicolumn{4}{|l|}{$\begin{array}{l}\text { Monetary incentives for } \\
\text { 'voluntary' return }\end{array}$} \\
\hline \multicolumn{4}{|l|}{ Increased return counselling } \\
\hline & $\begin{array}{l}\text { Cancellation of basic } \\
\text { welfare support }\end{array}$ & & \\
\hline $\begin{array}{l}\text { No cash benefits in return } \\
\text { centres }\end{array}$ & $\begin{array}{l}\text { Cancellation of cash } \\
\text { benefits for NRAS }\end{array}$ & & \\
\hline $\begin{array}{l}\text { Increasing the number of } \\
\text { deportations }\end{array}$ & 50.000 deportations & & \\
\hline
\end{tabular}

Source: Own compilation from 38 policies. 18 policies between 2015/09-2017/11

Table legend: - - - - = policy is adopted but deviates from tabled policy

2017 (Fremdenrechtsänderungsgesetz, FrÄG). The bills that are part of this package include the extension of detention while pending return, coercive detention in case of lacking cooperation with return, restricted movement, the installation of special return centres, and administrative penalties reaching 15,000 euros for failure to comply with a return decision and imprisonment as a substitute.

Further adopted policy responses in the field of return address external obstacles to return. These include the expansion of return agreements with third countries, the definition of "safe third countries" and "safe home countries", and a tighter collaboration with Frontex. This category also includes use of military planes for deportations - a topic that generated massive public attention in early 2016, as actors from both coalition parties bragged about their goal of "50,000 deportations" by 2019 . 
Against this background, public debate on rejected asylum seekers was to a considerable extent dominated by the Minister of Defence's plan to use military airplanes to carry out deportations. The idea sparked a sizeable and controversial discussion in the media. Ultimately, the planes were deemed suitable for deportations, but took place only twice.

Third, not all of the laws or return policy measures that were proposed or brought up in political debates were adopted. Three return policy measures that were not adopted include: a) the proposal to no longer preannounce deportations to destined deportees, b) to expand executive powers of the staff in reception and, more specifically, in return centres, ${ }^{5}$ and c) the initiation of a criminal procedure in case of nondeparture. This latter policy concerns the penalizing of irregular stay per se, after a rejected asylum application is unsuccessful in all its attempts. The initial proposal by the former Minister of the Interior to initiate a criminal prosecution in case a rejected asylum seeker exceeds the deadline for departure and cannot be deported by force, failed to be adopted. Instead, the above-mentioned administrative penalty was introduced for the same 'offense', which can be passed without a conviction.

None of the policies with links to social policy were adopted in the way they were proposed. Most importantly, the proposition of immediate cancellation of basic welfare support with a negative asylum decision (when NRAS do not cooperate with return) was not adopted, an outcome that we analyse in detail further below. The cancellation of cash-benefits was only adopted for those few transferred to return centres, not all NRAS. Below, we provide an analysis of these developments.

\subsubsection{Analysis}

Far from paying only lip-service to increasing deportations, the Austrian government has created several substantive policy responses to achieve this aim. Affirming the trend carved out in the literature on policies against irregular migration, we find that detention has again become a popular policy tool in Austria after 2015. All five major policy measures that were adopted in the course of FrÄG 2017 boil down to the instrument of forcible confinement. Two of these speak directly of detention, that is, the use of coercive detention against NRAS to make them take steps in their own departure and the prolongation of detention pending return from ten to 18 months. The other measures present a diversification of freedom-restricting policies, complementing or replacing the tool of detention. The government justified the necessity of return centres as preventing NRAS from going underground and strengthening incentives to leave. NRAS are placed in a return centre in cases when detention is not feasible. At the start of the debates on return centres, they were indeed discussed as a form of detention. The government argued for these centres:

\footnotetext{
${ }^{5}$ This proposal included the recognition of the return centres' staff as law enforcement authorities ("Organe der öffentlichen Aufsicht"), and subsequently gave them the power to issue orders and execute coercive measures against the centres' inhabitants (Brickner 2017).
} 
"Who doesn't leave, will be locked up" (Sterkl 2017). However, the result was the territorial restriction to a single district and the accommodation in return centres with increased return counselling aimed at restricting mobility to a confined area. These 'softer' forms of confinement equally confront NRAS with physical exclusion, control, and immobility.

The last measure in the adopted law package is the threat of an administrative penalty for failure to comply with a return decision, which starts at 5000 euros and can be as high as 15,000 euros. This is connected to detention in the sense that inability to pay results in imprisonment of up to 6 weeks. Considering this mostly unattainable cost, the penalty will very likely result in imprisonment in many cases. Most of these policies were also introduced into the debate as part of a graduated scheme. They followed the idea of tightening mobility restrictions according to the degree of unwillingness to leave the country, starting with confinement to the district, then the return centre, and culminating in coercive detention. Although the short-term nature of the analysed time period does not allow us to determine causation, detention numbers have risen dramatically since 2015. In 2017, a total of 4627 detentions were ordered, compared to 2434 in 2016 and 1436 orders in 2015 (Parlamentarische Anfrage 2018b). Hence in 2017, the number of detainees rose by 90\% (ORF 2018).

The diversified and multiple forms of confinement present a tool of immigration control. They are substantive measures to steer NRAS towards return and increase control to foster the deportation regime. Their punitive character serves the purpose of deterrence and physical exclusion to disincentivise NRAS to stay.

While post-2015 policy responses are mainly focused on forced return, the goal of fostering voluntary return has not vanished completely: one adopted policy introduced a monetary incentive scheme for voluntary return. Offering financial benefits for return complements the process of increasing disincentives to stay with a 'positive' incentive to leave. Similar to the various confinement measures, it follows a graduated scheme - the sooner a person leaves, the more money she receives - and therefore follows the idea of disciplining migrants to act in certain ways. However, since 2015, the percentage of voluntary returns in overall removals has decreased (Parlamentarische Anfrage 2018a: p.29), correlating with the overall punitive approach by the Austrian government against NRAS which prioritizes deportation over 'voluntary' return.

The relevance of the investigated policies, however, does not only and not mainly lie in the enforcement of deportations, but equally in how they aim to shape public perception of NRAS; in short, their symbolic relevance. Firstly, detention and confinement policies themselves have a symbolic dimension, marking NRAS as "threatening and dangerous" (Bosworth 2008). The multiple and diverse confinement policies signal that NRAS are to blame, and that one can punish them and lock them up like criminals. Moreover, as Bosworth demonstrates, "institutions of confinement like Immigration Removal Centres provide material evidence that the state is taking an issue seriously" (Ibid.: 211). Based on the adopted legal regulations, affected persons can be penalised if the degree of their cooperation with return is considered insufficient or simply because they are not leaving the national territory. 
In a nutshell, confinement instruments work "both symbolically and practically as a tool of border control" (Ibid.: 208).

In addition to the preponderance of control tools of forcible confinement, we also find in Austria policy responses whose symbolic character and intent is far more apparent than their relevance in handling the deportation gap. One example of such a symbolic policy is the use of military planes for deportations. The negligible impact of this policy — which was only twice put into effect—on the state's return policy bore no relation to its immense media publicity and examination procedures, which lasted several months. This measure was clearly symbolic, since it represented a more attention-grabbing substitute to other deportation flights, without any substantive increase of return numbers. The symbolism of shifting the issue of deportations from its customary political arena of domestic policy to the area of defence policy represents rejected asylum seekers as a threat to national security and signals control through the militarization of Austrian borders.

Simultaneously, asylum debates were increasingly superimposed with security concerns, coinciding with the killing of a woman in Vienna by a Kenyan citizen who was also a rejected asylum seeker. In the aftermath of this incident, the Ministry of the Interior announced an "Action Plan for the Safety of Austria" (Aktionsplan Sicherheit Österreich). Formally, it addressed all Austrian residents and citizens, but it repeatedly appeared in the same context with debates on "alien criminality", and therefore served a "rhetoric about the dangers inherent in foreigners" (Bosworth 2008: 200). The plan was directed at 'worried' citizens, while the measures in the plan predominantly targeted non-citizens. Such criminalisation of the entire status group of NRAS surfaced likewise in the yet unadopted policy proposal to file criminal charges for illegal residence.

The idea of restricting welfare entitlements for NRAS emerged as a migration policy tool especially in political debates, and less so in adoption. The proposed aim was to impel rejected asylum seekers to leave the country, but the proposals remained in the discourse gap and manifested as a symbolic intervention. Respective proposals were either not adopted, as in the case of cancelling basic welfare support, or only adopted with decisive reservations, as in the case of cancelling all cash benefits when transferred to a return centre. Notwithstanding the fact that in the bigger picture these harsh welfare restrictions were not feasible, the government was able to demonstrate that in their view NRAS were undeserving of such benefits.

In sum, we find a series of measures, mostly in the form of forcible confinement, which serve as policy instruments to achieve the substantive purpose of control and deterrence. At the same time, these harsh policy developments were complemented by symbolic proposals and measures that served the purpose of constructing NRAS as a security issue and stating their 'undeservingness'. 


\subsection{Discussion: Locating the Substantive and Symbolic Manifestations of the Post-2015 Policy Shift}

The policies analysed in this chapter articulate a very narrow understanding of problems and domestic policy solutions to the presence of rejected asylum seekers after 2015. Policy responses that have since prevailed aim either to enhance control over NRAS to facilitate their forced return or to convince the public of a strong commitment to this goal. How can we understand this policy shift from a regime of de facto toleration with a relatively inclusive welfare arrangement to the adoption of deterrent measures and criminalisation? First, we place the identified policy responses within a broader framework of policy and political changes of the post-2015 phase and, second, link them to the particular constraints to policy designs against irregular migration and NRAS and to the particularities of the Austrian federal political system (cf. Rosenberger 2018).

The described policy responses are part of more comprehensive domestic changes towards migration and asylum seekers in the post-2015 context. The government put forward various policy responses targeting the voting population's sceptical views on asylum seekers and refugees, such as a cap on the annual number of asylum applications, a temporary limitation of the granted protection status, the possibility of withdrawing protection status, and restrictions on welfare benefits. The main political aim of these measures was to demonstrate the restoration of control over migration and borders, deter future asylum seekers by making it more difficult to apply for asylum, and disincentivise the stay of refugees living in the country by making living conditions tough and unpleasant (Rosenberger and Müller forthcoming; Rutz 2018). Return enforcement as an instrument of state sovereignty was the narrow policy solution to the challenge that an even larger population without legalised stay presents. This tendency is also a Europe-wide approach. The European Commission (2017) published a recommendation outlining measures for making returns more effective and substantially increasing the rates of return through applying the EU's legal norms, especially the Return Directive. At the EU level, too, policy approaches pertain to the fields of creating disincentives to come and stay, as well as to eliminate barriers to the removal of rejected asylum seekers (Lutz 2018).

The policies reflected a general shift towards hostility: in a short period of time, the public mood and opinions within Austrian society changed from mostly welcoming to sceptical and anti-refugee views (Gruber 2017). Against this background, the polarising events of 2015 dominated emotionally-led election campaigns at both the federal and regional level (Plasser and Sommer 2017). Here, the issue of regaining control and sovereignty over borders became the main issue for both governing parties - independent of their position in the political spectrum-and the principle of strengthening internal and external borders has become the core aim of asylum and migration policy.

But as mentioned earlier in the chapter, certain return enforcement tools, especially detention, are limited by legal norms such as EU directives, the critique of 
human rights agencies, as well as a critique of their cost-inefficiency (Rechnungshof 2016). To bypass these constraints, the Austrian government has engaged in the multiplication and diversification of confinement policies. Already before 2015, the government had started to diversify its strategies by opening a detention centre in Vordernberg in 2014 exclusively for detaining persons awaiting removal, with the aim of achieving human rights standards and the requirements of the Return Directive (EMN 2016b). Another strategy involved using mechanisms like shortterm detention that do not appear in detention statistics. Through the multiplicity of tools to physically control NRAS, the government's policies aim to even out the systemic inconsistencies that manifest in the deportation gap. However, efforts of control alone are unlikely to nullify the various reasons why people are present even though they have been denied that right. Hence, seeking political popularity through a tough stance on return enforcement makes symbolic policies attractive, or maybe even necessary, to keep up the appearance of following through with the task.

In our case, it is also the particularities of the Austrian federal political system and resulting responsibilities between the federal government and provinces that limit substantive restrictions towards NRAS. The proposal that NRAS should be deprived of welfare benefits shows this discrepancy. The primary obstacle these proposals encountered is the constitutional rank of the Welfare Support Agreement of 2004 between the central government and the provinces, which makes NRAS an explicit target group of welfare entitlements. The implementation of restrictive policies was thus not possible. Still, the symbolic content of the proposed restrictions on welfare entitlements was intended to signal commitment to the audience, fuelling public narratives about the 'undeservingness' of NRAS. Further, this policy proposal was met with outright opposition from local government actors. In the debates, they stressed the hazard of potential consequences like rising destitution and homelessness. These impediments indicate why the deterrence mechanisms against NRAS are built primarily on return policy and, ultimately, less on welfare restrictions. The former is more effective, as it can be steered and enforced by the central government alone. Consequently, the central government's substantive aim of deterrence was enacted mainly through confinement policies, while welfare cuts were stuck in the discourse gap.

Contrary to substantive control policies, the problems being tackled through symbolic policies are not the actual impediments to return but the (homespun) increased public awareness of the deportation gap, which the government aims to soothe through the demonstration of sovereignty. In compliance with the abovementioned functions of symbolic policies categorized by Slaven and Boswell (2018), we depict the symbolic policies as a compensation mechanism for the state's sovereignty being called into question by the NRAS' presence. The use of military planes for deportation provides evidence of the ambition to reconstruct the tarnished state sovereignty by militarising return policies. The depiction of NRAS as a security issue, on the other hand, validates the ideological preconception of certain groups and "alter[s] the political climate" (Delaney 2002: 27) in order to gain legitimacy for harsh measures. This form of "manipulation" (Slaven and Boswell 2018: 2f), which we found for example in the policy suggestions in the context of the 
"Action Plan for the Safety of Austria" and the accompanying debate in the mass media (s. Rheindorf and Wodak 2018: 21), promotes the criminalisation of NRAS.

\subsection{Conclusions}

The chapter investigated policy responses directed at NRAS in Austria from 2015 to 2017, when Austria received a large amount of refugee arrivals. Based on an empirical analysis of government responses, we presented a number of findings. During this period, there was a significant increase in policy proposals focused on this group, which have pursued the direction of their deterrence with the unanimous aim of fostering the deportation regime. These policy proposals include features of punishment, like confinement instruments such as detention and return centres and, to a lesser extent, reductions in welfare benefits. Notably, the government has not adopted any political measures which support regularisation of the group, although the size of this group has been increasing since 2015. This means that the uncertain current situation and future of NRAS remain outside the scope of the political responses. However, we also find symbolic policies as a significant part of policy responses towards NRAS, on the one hand, as part of substantive policies and, on the other hand, as solely symbolic policies for signalling commitment and marking the 'threatening' and 'unwanted' figure.

This chapter contributes to the literature on irregular migration policy by analysing policies towards NRAS in Austria as a case study. We identify a variety of reasons that may explain the emergence of the policy turn described above. The restrictive policy development is part of a bundle of deterring measures directed against asylum seekers and refugees. This development forms part of a trend of the government itself, placing the issue on the political agenda thereby declaring its intent and claiming to reduce and be tough on asylum seekers and other unwanted migrants. For this policy turn, the so-called 'refugee crisis' presents a critical juncture and the crucial driver of its agenda. These single-sided policies may be identified as responses directed at voters in the first place to demonstrate the restoration of sovereignty over borders and people. This voter-oriented character, together with the legal and practical constraints on policies that facilitate deportation, explains why we found a mix of substantive and symbolic policies.

The timeframe of policies considered in the analysis of this chapter ends with November 2017. This is a limitation of this chapter, as in December 2017 the farright government, which ran on an explicit anti-migration agenda, came into office (see Regierungsprogramm 2017). Since then, policies producing a hostile environment, and in particular punitive policies, have become even more prevalent. Additionally, the policies at the intersection of welfare and migration are gaining in importance. In light of the discussed constraints to restrictive policies, it would be interesting to determine whether symbolic policies have become any more important, or whether the right-wing government coalition found other ways to 'deal' with those restrictions. 
In this chapter, we analysed the simultaneous production of substantive and symbolic policies. Our results illustrate more general European developments and point to avenues for further research and in-depth discussions about how effective control, detention, and welfare reductions are at steering individual behaviour while appeasing public opinion concerning tough measures against unwanted migrants. Future studies will have to investigate the dialectic of steering and signalling as well as the effectiveness of such policies for the reinforcement of the deportation regime. To do this, comparative studies will be useful to identify the role of national contexts, institutions, and political orientations in relation to the effects of these policies.

\section{References}

Ataç, I. (2019). Deserving shelter: Conditional access to accommodation for rejected asylum seekers in Austria, the Netherlands, and Sweden. Journal of Immigrant \& Refugee Studies, 16(1), 44-60. https://doi.org/10.1080/15562948.2018.1530401.

Ataç, I., \& Rosenberger, S. (2018). Introduction to the special issue: Social policies as a tool of migration control. Journal of Immigrant \& Refugee Studies, 16(1), 1-10. https://doi.org/10.10 80/15562948.2018.1539802.

Bagley, C., \& Ward, S. (2013). Policy response: A critical engagement. In A. Kollias (Ed.), The critical factors in the discourse on SL from the perspective of equity and learning (EPNoSL Project).

Bigo, D. (2005). From foreigners to 'abnormal aliens': How the faces of the enemy have changed following September the 11th. In E. Guild \& J. van Selm (Eds.), International migration and security: Opportunities and challenges (pp. 64-81). Abingdon: Routledge.

BMI. (2016). Asylstatistik 2016. https://www.bmi.gv.at/301/Statistiken/files/Jahresstatistiken/ Jahresstatistik_Asyl_2016.pdf. Accessed 16 May 2018.

Bosworth, M. (2008). Border control and the limits of state sovereignty. Social \& Legal Studies, 17(2), 199-215.

Brickner, I. (2017, February 25). Längere Schubhaft, hohe Geldstrafen: Koalition akkordiert Fremdenpaket. Der Standard. Online: https://derstandard.at/2000053172811/ Laengere-Schubhaft-hohe-Geldstrafen-Koalition-akkordiert-Fremdenpaket

Cantor, D. J., Wijk, J., Singer, S., \& Bolhuis, M. P. (2017). The Emperor's new clothing: National responses to 'undesirable and unreturnable' aliens under asylum and immigration law. Refugee Survey Quarterly, 36(1), 1-8.

Castles, S. (2004). The factors that make and unmake migration policies. International Migration Review, 38(3), 852-884.

Ceyhan, A., \& Tsoukala, A. (2002). The securitization of migration in Western societies: Ambivalent discourses and policies. Alternatives, 27(1), 21-39.

Czaika, M., \& de Haas, H. (2013). The effectiveness of immigration policies. Population and Development Review, 39(3), 487-508.

Delaney, J. G. (2002). Educational policy studies: A practical approach. Calgary: Detselig Enterprises.

EMN. (2016a). The return of rejected Asylum Seekers: Challenges and good practices. Available at https://www.emn.at/wp-content/uploads/2016/12/emn-studies-00_synthesis_report_rejected_ asylum_seekers_2016.pdf. Accessed 15 Aug 2018.

EMN. (2016b). The return of rejected Asylum-Seekers from Austria. Available at https://www. emn.at/wp-content/uploads/2016/12/The-return-of-rejected-asylum-seekers-from-Austria.pdf.

EMN. (2017). The effectiveness of return in EU Member States (Synthesis report for the EMN focussed study). Available at https://www.emn.at/wp-content/uploads/2017/12/EMN- 
Synthesis-Report-2017-The-effectiveness-of-return-in-EU-Member-States.pdf Accessed 15 Aug 2018.

European Commission. (2015). EU Action Plan on return. COM (2015) 453 final, Brussels, 9.9.2015.

European Commission. (2017). Communication from the Commission to the European Parliament and the Council on a more effective return policy in the European Union: a renewed Action Plan. Available at http://data.consilium.europa.eu/doc/document/ST-6943-2017-INIT/en/pdf

Eurostat. (2018). Asylum and first time asylum applicants by citizenship, age and sex. Monthly data (rounded). http://appsso.eurostat.ec.europa.eu/nui/submitViewTableAction.do.

Gibney, M. (2008). Asylum and the expansion of deportation in the United Kingdom. Government and Opposition, 43(2), 146-167.

Global Detention Project. (2017). Austria immigration detention. https://www.globaldetentionproject.org/countries/europe/austria.

Gruber, O. (2017). 'Refugees (no longer) welcome'. Asylum discourse and policy in Austria in the wake of the 2015 refugee crisis. In M. Barlai, B. Fähnrich, C. Griessler, \& M. Rhomberg (Eds.), The migrant crisis: European perspectives and national discourse (pp. 39-57). Zürich: LIT-Verlag.

Hamlin, R. (2012). Illegal refugees: Competing policy ideas and the rise of the regime of deterrence in American asylum politics. Refugee Survey Quarterly, 31(2), 33-53.

Hammerstad, A. (2014). The securitization of forced migration. In E. Fiddian-Qasmiyeh, G. Loescher, K. Long, \& N. Sigona (Eds.), The Oxford handbook of refugee and forced migration studies (pp. 265-277). Oxford: Oxford University Press.

Hansen, R. (2014). State controls: Borders, refugees, and citizenship. In E. Fiddian-Qasmiyeh, G. Loescher, K. Long, \& N. Sigona (Eds.), The Oxford handbook of refugee and forced migration studies (pp. 253-264). Oxford: Oxford University Press.

Heegaard Bausager, M. J., Møller, K., \& Ardittis, S. (2013). Study on the situation of third-country nationals pending return/removal in the EU Member States and the Schengen associated countries. European Commission, Home/2010/RFXX/PR/1001.

Hinterberger, K. F., \& Klammer, S. (2015). Das Rechtsinstitut der fremdenpolizeilichen Duldung. migraLex - Zeitschrift für Fremden- und Minderheitenrecht, 2015(3), 73-83.

Hollifield, J. F., Martin, P., \& Orrenius, P. M. (2014). Controlling immigration: A global perspective (3rd ed.). Stanford: Stanford University Press.

Joppke, C. (1998). Why Liberal states accept unwanted immigration. World Politics, 50(2), 266-293.

Krause, R. M. (2011). Symbolic or substantive policy? Measuring the extent of local commitment to climate protection. Environment and Planning C: Politics and Space, 29(1), 46-62.

Lahav, G., \& Guiraudon, V. (2006). Actors and venues in immigration control: Closing the gap between political demands and policy outcomes. West European Politics, 29(2), 201-223.

Leerkes, A., \& Broeders, D. (2013). Deportable and not so deportable: Formal and informal functions of administrative immigration detention. In B. Anderson, M. J. Gibney, \& E. Paoletti (Eds.), The social, political and historical contours of deportation (pp. 79-104). New York: Springer.

Lutz, F. (2018). Non-removable returnees under union law: Status quo and possible developments. European Journal of Migration and Law, 20(1), 28-52.

Majcher, I., \& de Senarclens, C. (2014). Discipline and punish? Analysis of the purposes of immigration detention in Europe. AmeriQuests, 11(2).

Massey, D. S., Arango, J., Hugo, G., Kouaouci, A., Pellegrino, A., \& Taylor, J. E. (2005). Worlds in motion: Understanding international migration at the end of the millennium. Oxford: Oxford University Press.

ORF. (2018). Zahl der Schubhäftlinge steigt enorm. Online: https://wien.orf.at/news/stories/2913180/, dated 17 May. Accessed 18 Sept 2018. 
Parlamentarische Anfrage. (2016). 7947/AB vom 18.04.2016 zu 8373/J (XXV.GP). https://www. parlament.gv.at/PAKT/VHG/XXV/AB/AB_07947/imfname_526034.pdf. Accessed 13 Sept 2018

Parlamentarische Anfrage. (2018a). 923/AB vom 19.07.2018 zu 936/J (XXVI.GP). https://www. parlament.gv.at/PAKT/VHG/XXVI/AB/AB_00923/imfname_705047.pdf. Accessed 13 Sept 2018.

Parlamentarische Anfrage. (2018b). 1001/AB vom 09.08.2018 zu 1018/J (XXVI.GP). https:// www.parlament.gv.at/PAKT/VHG/XXVI/AB/AB_01001/imfname_706803.pdf Accessed 18 Sept 2018.

Plasser, F., \& Sommer, F. (2017). Richtungswahl 2017. https://politische-akademie.at/userfiles/ files/downloads/Determinanten_und_Motive_der_Wahlentscheidung.pdf. Accessed 27 Apr 2018. Accessed 16 May 2018.

Rechnungshof. (2013). Flüchtlingsbetreuung der Länder Salzburg, Steiermark und Wien, Salzburg 2013/1.

Rechnungshof. (2016). Vollzug der Schubhaft mit Schwerpunkt Anhaltezentrum Vordernberg, Bund 2016/22.

Regierungsprogramm. (2013). Arbeitsprogramm der Bundesregierung 2013. https://www.justiz. gv.at/web2013/file/2c94848642ec5e0d0142fac7f7b9019a.de.0/regprogramm.pdf. Accessed 5 Sept 2018.

Regierungsprogramm. (2017). Zusammen. Für unser Österreich. Regierungsprogramm 20172022. https://www.oevp.at/download/Regierungsprogramm.pdf. Accessed 29 Apr 2018.

Rein, M. (2008). Reframing problematic policies. In R. E. Goodin, M. Moran, \& M. Rein (Eds.), The Oxford handbook of public policy (pp. 389-405). Oxford: Oxford University Press.

Rheindorf, M., \& Wodak, R. E. (2018). Borders, fences, and limits - Protecting Austria from refugees: Metadiscursive negotiation of meaning in the current refugee crisis. Journal of Immigrant and Refugee Studies, 16(1-2), 15-38.

Rosenberger, S. (2018). Navigating the representative-politics-Liberal-rights dilemma: Social policy designs for nonremoved migrants. Journal of Immigrant \& Refugee Studies, 16(1), 11-26. https://doi.org/10.1080/15562948.2018.1489089.

Rosenberger, S., \& Koppes, S. (2018). Claiming control: Cooperation with return as a condition for social benefits in Austria and the Netherlands. Comparative Migration Studies., 6, 26.

Rosenberger, S., \& Müller, S. (Forthcoming). Open and closed doors: Local responses to the refugee policy crisis in Austria. In B. Glorius \& J. Doomernik (Eds.), Geographies of Asylum in Europe and the role of European localities (IMISCOE research series). Cham: Springer.

Rutz, J. (2018). The changing influx of asylum seekers in 2014-2016: Austria's responses. Vienna: European Migration Network.

Sassen, S. (1988). The mobility of labour and capital. Cambridge: Cambridge University Press.

Scheel, S., \& Squire, V. (2014). Forced migrants as 'illegal' migrants. In E. Fiddian-Qasmiyeh, G. Loescher, K. Long, \& N. Sigona (Eds.), The Oxford handbook of refugee and forced migration studies (pp. 188-199). Oxford: Oxford University Press.

Schmoll, C. (2016). Controlling irregular migration. Policy options and unwanted consequences. In A. Triandafyllidou (Ed.), The Routledge migration and asylum handbook (pp. 361-370). Abingdon/New York: Routledge.

Scholten, P. (2013). Agenda dynamics and the multi-level governance of intractable policy controversies: The case of migrant integration policies in the Netherlands. Policy Sciences, 46(3), 217-236.

Schoukens, P., \& Buttiens, S. (2017). Social protection of non-removable rejected asylum-seekers in the EU: A legal assessment. European Journal of Social Security, 19(4), 313-334.

Schuster, L. (2011). Turning refugees into 'illegal migrants': Afghan asylum seekers in Europe. Ethnic and Racial Studies, 34(8), 1392-1407.

Slaven, M., \& Boswell, C. (2018). Why symbolise control? Irregular migration to the UK and symbolic policy-making in the 1960s. Journal of Ethnic and Migration Studies, 45(9), 1477-1495. 
Sterkl, M. (2017, February 1). Wer nicht geht, wird eingesperrt. Der Standard. Online: https:// derstandard.at/2000051873113/Wer-nicht-geht-wird-eingesperrt. Accessed 15 Aug 2018.

Stumpf, J. (2006). The Crimmigration crisis: Immigrants, crime, and sovereign power. American University Law Review, 56(2), 367-419.

Triandafyllidou, A. (2010). Irregular migration in Europe in the early 21st century. In A. Triandafyllidou (Ed.), Irregular migration in Europe. Myths and realities (pp. 1-21). Aldershot: Ashgate.

Triandafyllidou, A., \& Ambrosini, M. (2011). Irregular migration control in Italy and Greece: Strong fencing and weak gate-keeping serving the labour market. European Journal of Migration and Law, 13(3), 251-273.

Van Der Leun, J. (2006). Excluding illegal migrants in the Netherlands: Between national policies and local implementation. West European Politics, 29(2), 310-326.

Wyss, A. (2019). Stuck in mobility? Interrupted journeys of migrants with precarious legal status in Europe. Journal of Immigrant \& Refugee Studies, 16(1), 77-93. https://doi.org/10.1080/15 562948.2018.1514091.

Open Access This chapter is licensed under the terms of the Creative Commons Attribution 4.0 International License (http://creativecommons.org/licenses/by/4.0/), which permits use, sharing, adaptation, distribution and reproduction in any medium or format, as long as you give appropriate credit to the original author(s) and the source, provide a link to the Creative Commons license and indicate if changes were made.

The images or other third party material in this chapter are included in the chapter's Creative Commons license, unless indicated otherwise in a credit line to the material. If material is not included in the chapter's Creative Commons license and your intended use is not permitted by statutory regulation or exceeds the permitted use, you will need to obtain permission directly from the copyright holder.

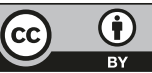

